\title{
Factors affecting sustained use of agricultural technologies: Case of cassava farmers in Southwest, Nigeria
}

\author{
Ogunsumi, Lucia Omobolanle
}

\author{
Institute of Agricultural Research and Training, Obafemi Awolowo \\ University, Ibadan, Nigeria., Corresponding E-mail:lucyogunsumi@yahoo.com
}

\begin{abstract}
The study on factors affecting sustained use of agricultural technologies the case of cassava farmers was carried out in three states of Southwest Nigeria. Structured interview schedules as well as in-depth study devices were used to collect data, which were analyzed using appropriate descriptive and inferential statistics. The study revealed that sustained users and abandoned users were not significantly different at $(5 \%)$ level in income level $(t=-0.85)$, educational level $(t=0.1 .08)$ and family size $(\mathrm{t}=-0.85)$. However, they were significantly different (at $5 \%$ level), in age $(\mathrm{t}=$ 2.17), farm size $(t=11.25)$ and cassava output $(t=10.87)$. The following major recommendations were made: (i) Agricultural technologies developed and disseminated should meet farmers' sociocultural, economic and environmental changing situations (ii) Technologies should be cost effective and flexible for result oriented adoption and adaptation (iii) Government should fund research and extension to enhance sustainable agriculture. (iv) Finally there should be adequate provision of inputs required for whole adoption of technologies other than the present experience where partial adoption occurred on the field. Regular evaluation and monitoring of output should be encouraged to affirm that the stipulated research results are realized.
\end{abstract}

Key words: Factor, sustained use, cassava and agricultural technologies

\section{INTRODUCTION:}

Cassava is of high importance to the people of Nigeria because of its perceived potential contribution to the total food intake of the populace. Notwithstanding, the apparent disregard in which producers and consumers hold it, it is eaten daily in one form or another by almost everyone. It is most commonly eaten in the paste form and almost invariably it is eaten with soup, vegetables, meat or beans. When eaten in such combination, the other food items provided the nutrients, vitamins and minerals lacking in cassava. Cassava also provides the calories necessary for energy and for efficient utilization of the protein.

Increasing farmers' productivity and income would require the development of appropriate technological method in research institutions and securing their transfer by means of an efficient extension system as well as sustaining their use according to Abalu $\mathrm{s}(1988)$. Research Institutions had not made much success in producing new technologies appropriate to the needs of African farmers in the post independence era (Spencer, 1986). To a large extent, failure has stemmed from inadequate understanding of small farmers' goals and resource limitations and over reliance on imported technologies from other regions (Rewald, 2001).

The general objective of the study is to identify factors affecting sustained use of adopted cassava technologies in Southwest, Nigeria.

The specific objectives are to:

1. examine the demographic characteristics of the farmers,

2. identify the adopted technologies in the study area with regards to cassava

3. identify factors that affect sustained use of adopted cassava technologies in the study area.

\section{RESEARCH METHODOLOGY}

The population for this study consists of the Agricultural Development Programmes' contact farmers in the Southwest zone, Nigeria currently involved in farming system practices, such that had adopted recommended technologies (maize, cassava and soybean) disseminated to them within a period between 1990 and 1995 or below.

The Sampling Procedure: The multi- stage sampling procedure was used to randomly select three states namely Oyo, Osun and Ondo where adoption (full or partial) of maize; cassava and 
soybean recommended technologies had been reported (IAR\&T, 2000)

The second stage of the sampling procedure consists of purposive selection of two zones of ADP per state, however only one zone was eventually considered fit for Ondo State for logistic reasons. This represents about 60 and 50 percent of the zones in the States respectively. The zones are Saki and Ibadan/lbarapa in Oyo State, Iwo and Ife/ljesha in Osun State and Akure in Ondo state.

Stage three consists of random selection of two blocks from the lists of blocks per zone where adoption of the technologies in question had taken place. The blocks selected were Saki, Igboho, Ido and Akinyele in Oyo State; Iwo, Ejigbo, ljebu jesha and Atakumosa in Osun State; Ishua and Ibule in Ondo State.

Stage four comprised of four cells selected randomly representing 50 percent of the selected blocks.

Lastly, stage five was the purposive random selection of three farmers' households who have sustained use of the technologies (in the three crops namely maize, cassava and soybean) and three farmers' households that abandoned the technologies from the list of farmers that had adopted the technologies. This was derived from a preliminary survey that was carried out with the assistance of Extension staff of the ADPs. This helped in identifying the farmers that had adopted selected technologies within a stipulated period of time.

\section{RESULTS AND DISCUSSION}

Demographic Characteristics of Respondents: The selected demographic characteristics of the respondents in this study were age, sex, marital status, level of education, religious affiliation, family size, gender of household head and organisational membership.

Mean age of respondents was 49 years ranging from 20 to 77 years (Table.1). The modal age group was 41-50 years. Almost half of the respondents (48.56\%) fell within the age bracket of 41-50 years. Those of 51-60 years make up only 30.29 percent of the respondents while those above 60-70 years were 5.77 percent and only 0.48 percent were above 70 years (Table 1 ). In addition, some 12.50 percent were within 31- 40 years age bracket, 1.92 percent were within 21-30 years of age and only 0.48 percent were a maximum of age 20 years old. A total of 14.90 percent of respondents fell below the modal age group, while a total of 36.54 percent rose above it. A large proportion of 78.85 percent were within the 4160 -age range.

Both male and female respondents were covered by the study. However, 91.35 percent of the respondents were male while only 8.65 percent were female (Table .1).

Table 1: Distribution of Respondents According to Age, Sex and Marital Status

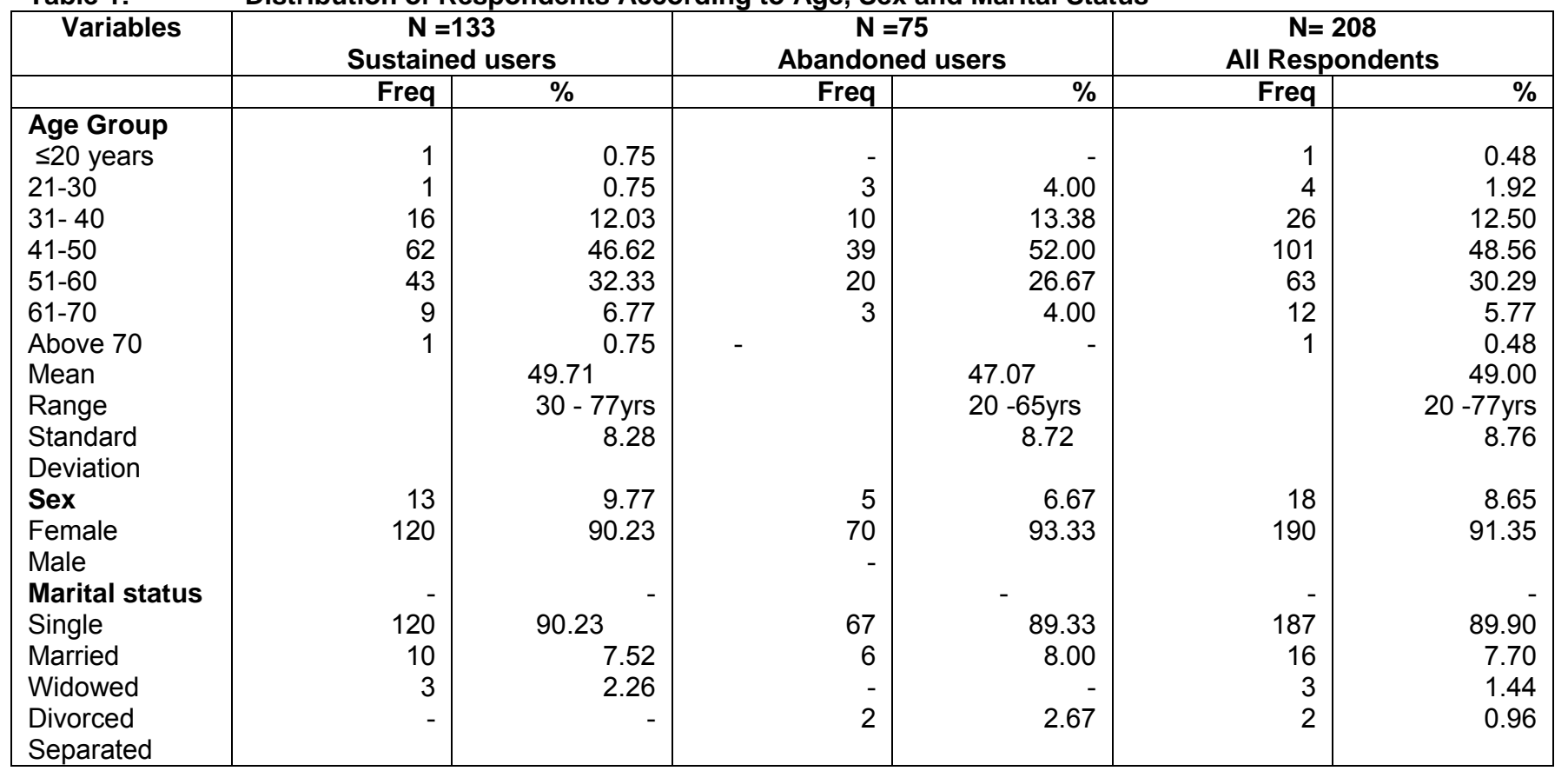


Majority of the respondents $(89.90 \%)$ were married. There was no unmarried farmer among the respondents. Only 7.70 percent of the respondents were widowed; 1.44 percent was divorced, while the rest $(0.96 \%)$ were separated (Table .1$)$. However a total of 10.1 percent of the respondents were living as single parents.

Figure 1 shows the educational level of respondents, 4.80 percent had no formal education, 5.29 percent had non-formal education (these include the group of respondents that attended remedial, extra moral and adult literacy classes). Only 2.89 percent attended primary schools while 24.52 percent of the respondents completed primary school.

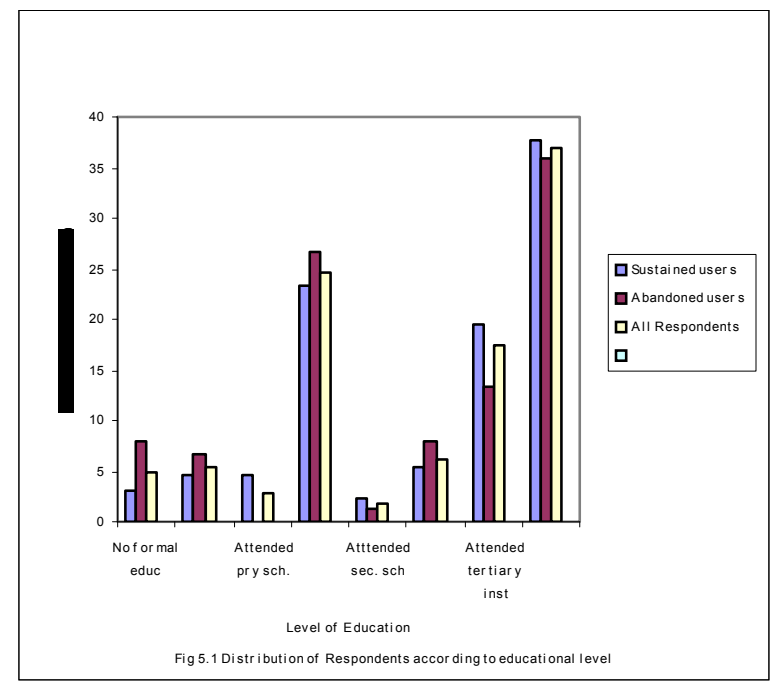

Only 1.92 percent of the respondents attended secondary schools while 6.25 percent completed secondary school. Some 17.31 percent of respondents attended tertiary institutions, which includes those respondents that attended Teachers Training colleges, Colleges of education, among others. The rest of the respondents $(37.02 \%)$ were the groups of respondents that completed tertiary institutions, which includes those respondents that completed Teachers Training colleges, Colleges of education, Polytechnics and Universities among others (Fig.1). In other words, majority of respondents $(60.58 \%)$ completed at least secondary schools while a total of 29.33 percent of respondents attended primary schools or at most attended secondary schools.

A total of 151 respondents from the 208-sample size responded to question on social status (Table 2). Only 7.95 percent of the respondents were village heads while 12.58 percent of them had one form of chieftaincy title or the other. However majority of them $(77.48 \%)$ were household heads. Only 1.99 percent belonged to other forms of social statuses, which include head of society, organisation or religious groups (Table 2)

Majority of farmers $(59.62 \%)$ were Christians while 38.46 percent were Moslems and only 1.92 percent were traditional worshippers (Table 2).

Table 2 Distribution of Respondents According to their Social Status and Religious Affiliation

\section{Group Sustained users Abandoned users All}

Respondents

\begin{tabular}{|c|c|c|c|c|c|c|}
\hline & Freq & $\%$ & Freq & $\%$ & Freq & \\
\hline Group & $\mathrm{N}=96$ & & $\mathrm{~N}=55$ & & $\mathrm{~N}=151$ & \\
\hline \multicolumn{7}{|l|}{ Social status } \\
\hline Village Head & 8 & 8.33 & & 7.27 & 12 & 7.95 \\
\hline Chieftaincy title & 15 & 15.63 & 4 & 7.27 & 19 & 12.58 \\
\hline Household head & 72 & 75.00 & 45 & 81.82 & 117 & 77.48 \\
\hline Others & 1 & 1.04 & 2 & 3.64 & 3 & 1.99 \\
\hline \multicolumn{7}{|l|}{ Religious Denomination } \\
\hline & & $N=133$ & & $N=75$ & & $\mathrm{~N}=\mathbf{2 0 8}$ \\
\hline $\begin{array}{l}\text { Christianity } \\
\text { Islam }\end{array}$ & 74 & 55.64 & 50 & 66.67 & 124 & 59.62 \\
\hline \multirow[t]{2}{*}{ Traditional worshipers } & 57 & 42.86 & 23 & 30.67 & 80 & 38.46 \\
\hline & 2 & 1.50 & 2 & 2.67 & 4 & 1.92 \\
\hline
\end{tabular}


Table 3 : Distribution of Respondents According to Cassava Output (Tons)

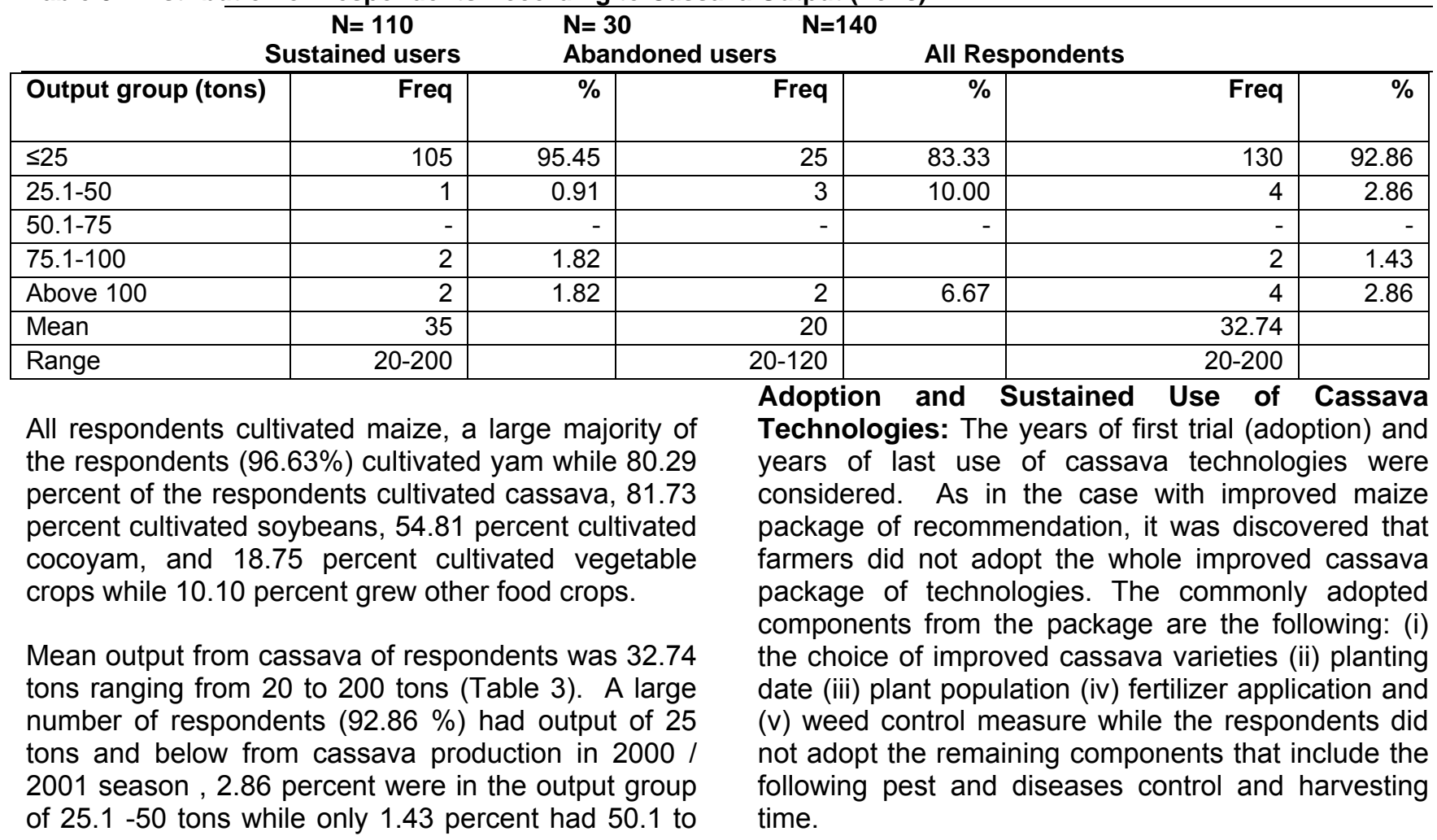
100 tons and the rest 2.86 percent had above 100 tons.

Table 4: Adoption Status of Cassava Improved Technology.

\section{Characteristic}

\begin{tabular}{|c|c|c|c|c|c|c|}
\hline & Freq. & $\%$ & Freq & $\%$ & Freq & $\%$ \\
\hline \multicolumn{7}{|c|}{ Improved cassava package of technologies } \\
\hline \multicolumn{7}{|l|}{ Year $1^{\text {st }}$ heard } \\
\hline $1-5$ & - & 1.50 & - & - & 2 & 0.96 \\
\hline $6-10$ & 17 & 0.75 & 7 & 9.33 & 8 & 3.85 \\
\hline $11-15$ & 93 & 63.91 & 57 & 76.00 & 142 & 68.27 \\
\hline $16-20$ & 23 & 33.83 & 11 & 14.67 & 56 & 26.92 \\
\hline \multicolumn{7}{|l|}{$1^{\text {st }}$ trial (Yrs) /Adoption level } \\
\hline $1-5$ & - & 12.78 & - & - & 2 & 0.96 \\
\hline $6-10$ & 17 & 69.92 & 7 & 9.33 & 8 & 3.85 \\
\hline $11-15$ & 93 & 17.29 & 57 & 76.00 & 142 & 68.27 \\
\hline $16-20$ & 23 & & 11 & 14.67 & 56 & 26.92 \\
\hline \multicolumn{7}{|l|}{ Last used / Sustained / Abandoned } \\
\hline Still Using & 133 & 100.00 & - & - & 133 & 63.94 \\
\hline $1-5$ & - & - & 31 & 41.33 & 31 & 14.90 \\
\hline $6-10$ & - & - & 36 & 48.00 & 36 & 17.31 \\
\hline $11-15$ & - & - & 8 & 10.67 & 8 & 3.80 \\
\hline $16-20$ & - & - & - & - & - & - \\
\hline
\end{tabular}

since $11-15$ years ago. That group was followed by 17.80 percent of the respondents who used the 
The period of last use of cassava technology was also considered. Similarly 63.94 percent of the respondents were still using the technology. These respondents were the sustained users of cassava technology while the rest 36.04 percent were the abandoned users. However, they stopped the use of the technology at varying times. Those respondents that stopped using the technology since $1-5$ years were 14.9 percent. About 17 percent stopped the use since $6-10$ years while 3.8 percent 118stopped since 11 - 15 years ago (Table 4 ).

Table 5 : Factors Affecting Sustainability of Cassava Technology Among Respondents.

\begin{tabular}{|c|c|c|c|c|c|c|c|c|}
\hline \multirow[t]{2}{*}{ Factors } & \multicolumn{4}{|c|}{ Sustained users } & \multicolumn{4}{|c|}{ Abandoned users } \\
\hline & 0 & 1 & 2 & 3 & 0 & 1 & 2 & 3 \\
\hline $\begin{array}{l}\text { Availasbility of } \\
\text { Capital }\end{array}$ & $\begin{array}{l}37 \\
(27.82)\end{array}$ & $\begin{array}{l}96 \\
(72.20)\end{array}$ & - & - & $15(20.0)$ & $60(80.0)$ & - & - \\
\hline Returns/ Income from practice & $\begin{array}{l}37 \\
(27.82)\end{array}$ & $\begin{array}{l}20 \\
(15.04)\end{array}$ & $\begin{array}{l}76 \\
(36.54)\end{array}$ & - & $15(7.21)$ & $13(6.25)$ & $47(22.60)$ & - \\
\hline $\begin{array}{l}\text { Cost of practicing } \\
\text { Technology }\end{array}$ & $\begin{array}{l}37 \\
(27.82)\end{array}$ & $\begin{array}{l}25 \\
(18.80)\end{array}$ & $\begin{array}{l}33 \\
(24.80)\end{array}$ & $\begin{array}{l}38 \\
(28.60)\end{array}$ & $15(20.0)$ & $15(20.0$ & $24(32.0)$ & $21(28.0)$ \\
\hline Cost of technology itself & $\begin{array}{l}37 \\
(27.82)\end{array}$ & - & $\begin{array}{l}96 \\
(72.20)\end{array}$ & - & $15(20.0)$ & $60(80.0)$ & & - \\
\hline Cost of input & $\begin{array}{l}37 \\
(27.82)\end{array}$ & $\begin{array}{l}38 \\
(28.60)\end{array}$ & $\begin{array}{l}58 \\
(43.60)\end{array}$ & - & $15(20.0)$ & $21(28.0)$ & $39(52.0)$ & - \\
\hline $\begin{array}{l}\text { Cultural } \\
\text { Adaptability }\end{array}$ & $37(27.82)$ & $12(9.00)$ & $59(44.40)$ & $25(18.80)$ & $15(20.0)$ & $9(12.0)$ & $36(48.0)$ & $15(20.0)$ \\
\hline $\begin{array}{l}\text { Social } \\
\text { Adaptability }\end{array}$ & $37(27.82)$ & $57(42.90)$ & $38(28.60)$ & $1(0.80)$ & $15(20.0)$ & $33(44.0)$ & $25(33.3)$ & $2(2.7)$ \\
\hline Availability of technology & $38(28.57)$ & - & $95(71.4)$ & - & $17(22.7)$ & - & $58(77.3)$ & - \\
\hline Availability of input & $38(28.57)$ & $57(42.9)$ & $1(0.8)$ & $37(27.8)$ & $16(21.3)$ & $33(44.0)$ & $2(2.7)$ & $24(32.0)$ \\
\hline Yield or output & $37(27.82)$ & $71(53.4)$ & $25(18.8)$ & - & $15(20.0)$ & - & $45(60.0)$ & $15(20.0)$ \\
\hline Storage quality & $37(27.82)$ & $21(15.8)$ & $13(9.8)$ & $62(46.8)$ & $15(20.0)$ & $15(20.0)$ & $10(13.3)$ & $35(46.7)$ \\
\hline Environmental adaptation & - & $20(15.0)$ & $113(85.0)$ & - & - & $13(17.3)$ & $62(82.7)$ & - \\
\hline $\begin{array}{l}\text { Land tenure } \\
\text { Problems }\end{array}$ & & & $37(27.8)$ & $96(72.2)$ & - & - & $24(32.0)$ & $51(68.0)$ \\
\hline $\begin{array}{l}\text { Inconsistencies in } \\
\text { Government policies }\end{array}$ & - & $20(15.0)$ & $38(28.6)$ & $75(56.4)$ & - & $27(36.0)$ & $20(26.7)$ & $42(56.0)$ \\
\hline
\end{tabular}

Figures in parenthesis - percentages

Key: 0=Indifferent, 1-3= Rating scale 3= Most important reason, 2= Moderate important reason ,1=least important reason.

Factors Affecting the Sustained Use of Cassava Technology: Rating scale of 1 to 3 was employed in ranking factors and reasons for sustaining or abandoning cassava technology in the study area. Majority of the respondents $(72.20 \%)$ ranked land tenure system as the most pressing factor for sustaining cassava technologies while 56.4 percent ranked inconsistencies in government policies as the next most pressing reason. Less than half $(46.80 \%)$ of the respondents also ranked storage quality as most important factors, this is followed by 28.60 percent of the respondents. Other most pressing reasons are as follow according to their ranking order; cost of practicing the technology $(28.60 \%)$, availability of input $(27.80 \%)$, and cultural adaptability $(18.80 \%)$ while social adaptability was rated by only 0.80 percent. At most, 28.57 percent of respondents were indifferent to the ranking of the factors. Environmental adaptation was ranked as highest moderate pressing factor by 85 percent of the respondents. Followed by this is, cost of technology rated by 72.20 percent and 71.40 percent rated availability of technology. Other factors according to respondents' rating include the following; availability of technology $(71.40 \%)$, returns from practice $(57.14 \%)$ cultural adaptability $(44.40 \%)$, cost of input $(43.6 \%)$ and availability of input which was rated least $(0.8 \%)$ (Table 5$)$.

Similarly, majority $(72.20 \%)$ rated availability of capital as the least pressing reason for sustaining the technology; followed by Yield or output $(53.40 \%)$, availability of input/ social adaptability $(42.9 \%)$ and cultural adaptability had the least $(9.00 \%)$ among others (Table 5).

However, there were significant differences between some other demographic variables using $\mathrm{T}$ - test analysis such are, age and sustained use of 
technology at $t$ value of -2.17 and farm size of respondents $(t=11.25)$ (Table 6$)$. Others with no significant differences include the following; family size $(\mathrm{t}=-\mathrm{-} .85)$, educational level $(\mathrm{t}=1.08)$ and income level (t-value $=-0.85)$, (Table 6).

Table 6: Summary of T- Test Analyses of Selected Variables between the Sustained Users and Abandoned Users.

\begin{tabular}{|c|c|c|c|c|c|}
\hline & \multicolumn{2}{|r|}{ Sustained users } & \multicolumn{2}{|c|}{ Abandoned users } & \multirow[b]{2}{*}{ T-test } \\
\hline Variables & Mean & $\begin{array}{l}\text { Standard } \\
\text { deviation }\end{array}$ & Mean & $\begin{array}{l}\text { Standard } \\
\text { deviation }\end{array}$ & \\
\hline Age (yrs) & 49.70 & 8.28 & 47.00 & 8.72 & $-2.17^{*}$ \\
\hline Farm size (ha) & 6.04 & 5.20 & 6.39 & 5.3 & $11.25^{*}$ \\
\hline Family size & 9.11 & 5.87 & 8.41 & 5.47 & -0.85 \\
\hline $\begin{array}{l}\text { Educational level } \\
\text { (years) }\end{array}$ & 8.29 & 6.40 & 7.26 & 5.21 & 1.08 \\
\hline Income $(\mathrm{N})$ & $56,839.47$ & 16078.86 & $57,910.67$ & 12828.33 & -0.85 \\
\hline Cassava output & 85,0977 & 321.43 & 65.20 & 226.53 & 1.08 \\
\hline Maize output & 52.11 & 226.32 & 46.08 & 172.50 & 2.13 \\
\hline Cassava output & 18.62 & 214.68 & 16.00 & 138.56 & $10.87^{*}$ \\
\hline
\end{tabular}

\section{REFERENCES:}

Abalu GO.I. (1988). "Building and Institutionalising an Effective Agricultural Technology Transfer Process in Nigeria: Research and Extension for More Food and Income to Farmers". Proceedings of the Second Annual Farming Systems Research and Extension Workshop in South Eastern Nigeria. Umudike. January $10-14$.

Ogunsumi L O. (2004).Analysis of Sustained use of Agricultural Technologies on Farmers' Productivity in Southwest Nigeria, Unpublished Ph. D. Thesis, Federal University of Technology, Akure, Nigeria.
Malton M and D. S. C. Spencer (1984). Increase food in sub- Station of African journal of Agricultural Economic vol $66 \mathrm{Pp} 71-76$.

Spencer D.S.C. (1986). Agricultural Research of past strategies for African Development University of California.

Rewald, M. (2001). Success and failure in achieving the goals of the world food summit in Proceeding of an international conference. Sustainable food security for All by 2020. Held at Bonn, Germany, September 4 -6, 2001 Pp $21-22$.

Institute of Agricultural Research and Training (I. A. R. \&T.) (2000). The Impact Assessment Report of proven Technologies N.A.R.P. report. 